\title{
Species delimitation and inter-specific gene flow in Tamarix L. (Tamaricaceae)
}

\author{
Masoud Sheidai ${ }^{1}(\mathbb{D})$, Tahmineh Shagholi ${ }^{2}$, Maryam Keshavarzi ${ }^{2}$ (i), \\ Fahimeh Koohdar, ${ }^{1, *}$ (i) \& Habibollah ljbari ${ }^{3}$
}

Key words: Tamarix, ITS, HGT tree, Species delimitation.

Ključne besede: Tamarix, ITS, drevo HGT, razmejitev vrst.

Received: 24. 7. 2018

Revision received: 21. 1. 2019

Accepted: 21. 1. 2019

\begin{abstract}
Tamarix L. play important role in preventing deforestation in Iran. Tamarix species exhibit wide range of morphological variation therefore, the species delimitation become difficult. This is further complicated due to similarity of morphological characters in closely related species and the occurrence of interspecific hybridization. The present study was performed to identify Tamarix species and their potential hybrids in Semnan Province of Iran. We used ITS and ISSR and 42 morphological characters for our investigation. Molecular phylogeny of the studied species and their relationship was not in agreement with the species tree of morphological characters and with taxonomic treatment of the genus. HGT tree of ITS and morphological data obtained revealed the occurrence of inter-specific hybridization or introgression between Tamarix species.

Izvleček

Vrste rodu Tamarix so v Iranu pomembne za preprečevanje krčenja gozdov. Zanje je značilna široka morfološka variabilnost, $s$ katero so sposobne preživeti v različnih ekoloških razmerah, zato je razmejitev vrst težavna. Dodatne težave predstavljajo podobni morfološki znaki pri ozko sorodnih vrstah in prisotnost medvrstnega križanja. V članku želimo določiti vrste rodu Tamarix in njihove potencialne križance iz province Semnan v Iranu. V raziskavi smo uporabili ITS in ISSR molekulske markerje in 42 morfoloških znakov. Molekularna filogenija obravnavanih vrst in njihova razmerja niso bili v skladu z dendrogramom morfoloških znakov in s taksonomsko členitvijo rodu. Z HGT dendrogramom podatkov iz ITS in morfološko analizo smo pokazali obstoj medvrstnega križanja oziroma introgresije med vrstami rodu Tamarix.
\end{abstract}




\section{Introduction}

The genus Tamarix L. contains about 54 species that mainly grow in saline areas of deserts and semi-deserts in Asia, Europe, North-east and South-west of Africa. Tamarix species play important role in preventing deforestation in Iran (Sheidai et al. 2018). Tamarix species have limited benefits to human but have been used as ornamental plant in gardens or public plantations. For example, T. gallica L., T. chinensis Lour., T. ramosissima Ledeb. are frequently used as ornamental plants for their feathery appearance and their catkin-like inflorescences (Gaskin 2003). Tamarix species are good for windbreak (for example T. aphylla (L.) Karst. and T. Africana Poir.) or for erosion control and easily grow in poor soils (Baum 1967, Gaskin and Schaal 2002, Ijbari et al. 2014).
Tamarix species hybridize and may form different taxonomic forms due to inter-specific hybridization and introgression (Gaskin \& Schaal 2003, Gaskin \& Kazmer 2019, Mayonde et al. 2019). Due to different degree of gene flow among Tamarix species, plants with variable morphological characters occur in the same area. Therefore, high gene flow in Tamarix species caused by interspecific hybridization resulting in phenotypic variations have rendered taxonomic classification of the genus problematic (Baum 1978, Ijbari et al. 2014). T. tetrandra Pall. ex M.Bieb., T. gallica L., T. chinensis, T. ramosissima, and T. parviflora DC. are considered to be one variable species or hybridizing group, designated by the hybrid name T. pentandra Pall. (Sudbrock 1993). T. chinensis and T. ramosissima are morphologically alike and differ only in some microscopic characters and genetically distinct in Asia (Mayonde et al. 2016). However,

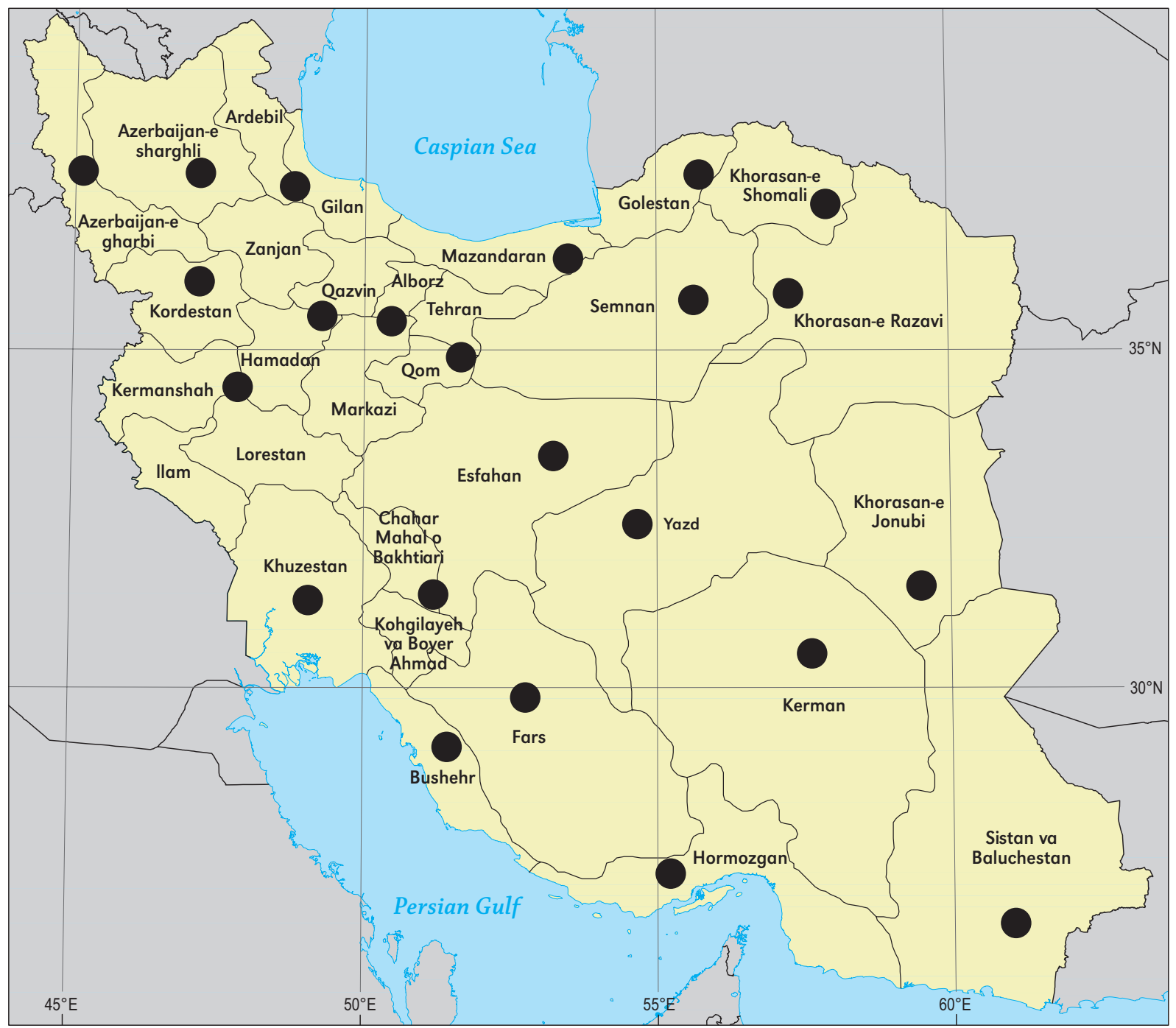

Figure 1: Distribution map of Tamarix species in Iran. Slika 1: Karta razširjenosti vrst rodu Tamarix v Iranu. 
they have been proven to be genetically different and are known to hybridize in North America and South Africa (Gaskin \& Schaal 2002, Gaskin \& Kazmer 2009, Mayonde et al. 2016).

Morphological characteristics are important in Tamar$i x$ species delimitation. Tamarix leaves are taxonomically useful and they show variation in shape and attachment modes in different species (Baum 1978). Tamarix flowers are bisexual, rarely unisexual and plants are either monoecious or dioecious. The flowers either have five or four sepals with corresponding number of petals. Flowers have five or numerous stamens that are free or fused and are inserted into a fleshy, glandular, hypogynous disc (Obermeyer 1976, Baum 1978). The presence of bisexual flowers and cross-pollination in Tamarix lead to the occurrence of high genetic diversity and hybrid formation in these species (Gaskin \& Schaal 2002, Gaskin \& Kazmer 2009, Gaskin et al. 2012, Mayonde et al. 2015, 2016). The intraspecific genetic variability may be used for local adaptation and also prevents homozygosity and genetic extinction of the studied Tamarix taxa (Ijbari et al. 2014).

Thirty-five Tamarix species occur in Iran as reported by Schiman-Czeika (1980). These species have been used in plantation to prevent deforestation in Iran. However, our general survey and extensive collections in different provinces may suggest the occurrence of more number of species/ sub-species in the country. The correct identity of our Tamarix collections can be verified at population level through detailed taxonomic investigations using both morphological and molecular approaches (Arianmanesh et al. 2014, Ijbari et al. 2014).

Tamarix species occur in 21 provinces of Iran (Figure 1). Ecological and climatic differences may influence the morphological appearance of Tamarix but will not affect the identity of the species (Sheidai et al. 2018). Despite the phenotypic differences in our plant collection and the previous studies observed in different localities, we hypothesized that the identities are most likely to be the same. Due to co-occurrence of two or three Tamarix species in overlapping areas, it is very important to identify and delimit these species. Moreover, due to frequent gene exchange between species in the same area there is high probability of hybrid formation. Therefore, it is necessary to highlight gene flow among the species growing within each locality (Ijbari et al. 2014, Sheidai et al. 2018).

Molecular tools in systematic provide the means to investigate the identity of different plant species at the DNA level, showing genetic variation within and among populations, and can also detect introgression patterns between closely related species (Le Roux \& Wieczorek
2008). ITS sequences are useful to construct phylogenies of angiosperms at lower taxonomic levels (Baldwin et al. 1995) and reveal polymorphisms (double base readings) within plant individuals (Campbell et al. 1997). Polymorphisms in some individuals can occur because concerted evolution is not fast enough to homogenize repeats of mutations among the multiple copies in the genome, and/or because of recent hybridization events (Campbell et al. 1997). ISSR molecular markers were shown to be informative for genetic diversity and population structure studies (see for example, Sheidai et al. 2012, 2013, Azizi et al. 2014).

Our study was conducted in the Semnan Province of Iran because species of this area have not been identified. After morphological identification of Tamarix species, their identification was also checked by BLAST using ITS (Internal transcribed sequences) of the nuclear DNA (nrDNA). Furthermore, the morphological and ITS analyses of identified species were carried to reveal the species delimitation and relationship (Sheidai et al. 2013, Minaeifar et al. 2016) and we carried out introgression patterns in populations of in T. szowitsiana Bge. and T. androssowii Litv. species by using Inter-simple sequence repeats (ISSR) and in T. Androssowii, T. Meyerii Boiss. and T. Szowitsiana by ITS molecular markers.

\section{Materials and methods}

\subsection{Morphological investigation}

Eighty plants were randomly collected from 22 geographically areas in Semnan Province in Iran and used for morphological investigations. The voucher specimens were deposited in Herbarium of Shahid Beheshti University (HSBU) (Table 1).

Morphological characters (Table 2) used are according to Ijbari et al. (2014). Morphological data were standardized (Mean $=0$, Variance $=1$ ) and used to estimate Euclidean distance. Grouping of the species was done by UPGMA (Unweighted paired group using average method) clustering and principal coordinate analysis ( $\mathrm{PCoA})$ (Podani 2000). These analyses were done using PAST ver. 2.17 (Hammer et al. 2012).

\subsection{Molecular investigations}

For molecular analyses, we used both the multilocus genome-wide markers (i.e. ISSR) and the single locus (i.e. ITS 1, 5.8S, ITS2) regions. Both markers were used for species diversity analysis and phylogeny (Weising et al. 2005, Sheidai et al. 2014). 
Table 1: Geographic areas studied and ecological features.

Tabela 1: Obravnavana geografska območja in njihove ekološke značilnosti.

\begin{tabular}{lllllll}
$\begin{array}{l}\text { Number of } \\
\text { locality }\end{array}$ & Province & Locality & $\begin{array}{l}\text { Altitude } \\
(\mathbf{m})\end{array}$ & Longitude & Latitude & $\begin{array}{l}\text { Voucher } \\
\text { number }\end{array}$ \\
\hline 1 & Semnan & Bagh village & 1109 & 36.12507 & 54.26741 & 1294 \\
2 & Semnan & 10 km to Garmsar & 1033 & 35.19760 & 52.60075 & 1394 \\
3 & Semnan & $5 \mathrm{~km}$ to Damghan & 1146 & 36.7152 & 54.15927 & 1494 \\
4 & Semnan & Sorkheh & 1149 & 35.27208 & 53.10930 & 1594 \\
5 & Semnan & 10 km to Semnan & 1165 & 35.30488 & 53.17239 & 1694 \\
6 & Semnan & Bagh village & 1109 & 36.12507 & 54.26741 & 1794 \\
7 & Semnan & $5 \mathrm{~km}$ to Damghan & 1146 & 36.7152 & 54.15927 & 1894 \\
8 & Semnan & $50 \mathrm{~km}$ to Chesameh ali villag & 1395 & 36.15214 & 54.9535 & 1994 \\
9 & Semnan & 20 km to Chesameh ali villag & 1400 & 36.15169 & 54.9289 & 2194 \\
10 & Semnan & Chesameh ali villag & 1376 & 36.14671 & 54.10539 & 2294 \\
11 & Semnan & 25 km to Garmsar & 1033 & 35.19760 & 52.6075 & 2394 \\
12 & Semnan & 20 km to Garmsar & 995 & 35.18984 & 52.7327 & 2594 \\
13 & Semnan & 10 km to Garmsar & 844 & 35.14412 & 52.17773 & 2694 \\
14 & Semnan & 20 km to Garmsar & 995 & 35.18984 & 52.7327 & 2794 \\
15 & Semnan & Bagh village & 1109 & 36.12507 & 54.26741 & 2894 \\
16 & Semnan & $5 \mathrm{~km}$ to Damghan & 1146 & 36.7152 & 54.15927 & 2994 \\
17 & Semnan & Amiriyeh villag & 1144 & 36.6482 & 54.14472 & 3294 \\
18 & Semnan & Turan Protected Area & 1007 & 36.28135 & 55.42987 & 3394 \\
19 & Semnan & Hadad village & 1124 & 36.16662 & 54.44510 & 3494 \\
20 & Semnan & 20 km to Shahrood & 1114 & 36.12805 & 54.29208 & 3694 \\
21 & Semnan & 10 km to Semnan & 909 & 35.14338 & 52.24440 & 3794 \\
22 & Semnan & $10 \mathrm{~km}$ to Sorkheh & 903 & 35.14463 & 52.24709 & 3894 \\
\hline
\end{tabular}

Table 2: Morphology characteristics in Tamarix.

Tabela 2: Morfološke značilnosti vrst rodu Tamarix.

\section{No Characters}

1 leaf length

2 length of inflorescence

3 width of inflorescence

4 ratio of leaflet size/ pedicel size

5 ratio of leaflet size/ calyx size

6 length of leaflet

7 width of leaflet

8 ratio of pedicel size/ calyx size

9 calyx segments

10 length of internal calyx

11 length of external calyx

12 width of internal calyx

13 width of external calyx

14 corolla segments

15 corolla length

16 corolla width

17 stamen number

18 anther length

19 anther width

20 disc diameter stem pile

\subsubsection{DNA extraction}

Fresh leaves were randomly collected from 5-10 Tamarix trees in each population. CTAB activated charcoal protocol was used to extract genomic DNA (Križman et al. 2006). The quality of extracted DNA was examined by running on $0.8 \%$ agarose gel.

\subsubsection{ITS analysis}

ITS region DNA was amplified with $0.2 \mu \mathrm{M}$ primer ITS1 (5' TCCGTAGGTGAACCTGCGG-3', Bioron, Germany), and primer ITS4 (5'- TCC GCT TATTGA TAT GC -3') (Chen et al. 2010). PCR reactions were performed in a $25 \mu \mathrm{l}$ volume containing $10 \mathrm{mM}$ Tris- $\mathrm{HCl}$ buffer at $\mathrm{pH} 8 ; 50 \mathrm{mM} \mathrm{KCl} ; 1.5 \mathrm{mM} \mathrm{MgCl}$; $0.2 \mathrm{mM}$ of each dNTP (Bioron, Germany), 20 ng genomic DNA and $3 \mathrm{U}$ of Taq DNA polymerase (Bioron, Germany). The amplification reaction was performed in a Techne thermocycler (Germany) using the following parameters: 2 min initial denaturation step at $94^{\circ} \mathrm{C}$, followed by 35 cycles of 5 min at $94^{\circ} \mathrm{C} ; 1.30 \mathrm{~min}$ at $56^{\circ} \mathrm{C}$ and 2 min at $72^{\circ} \mathrm{C}$. The reaction was completed by a final extension step of $7 \mathrm{~min}$ at $72{ }^{\circ} \mathrm{C}$. PCR products were visualized on $2.5 \%$ agarose gels with GelRed ${ }^{\mathrm{TM}}$ Nucleic Acid Gel Staining. 
Fragment sizes were estimated using a $100 \mathrm{bp}$ size ladder (Thermo- Fisher Scientific, Waltham, MA USA).

ITS sequences obtained were aligned with MUSCLE (Robert 2004) implemented in MEGA 5. The molecular clock test was performed as implemented in MEGA 5 (Tamura et al. 2011). The test was done by comparing the ML value for the given topology with and without the molecular clock constraints under the Tamura and Nei (1993) model. Different phylogenetic trees were obtained from ITS data like UPGMA (Unweighted paired group using average), Neighbor Joining (NJ) and Maximum likelihood (ML) methods. Hundred times bootstrapping was used for final trees.

\subsubsection{ISSR analysis}

7 ISSR (inter simple sequence repeat) primers UBC810, UBC849, (CA) 7AC, (GA) 9T, (GA) 9A and (AGC) 5GG were used according to Ijbari et al. (2014) and were purchased from University of British Columbia, Canada. The polymerase chain reaction (PCR) reactions were performed in a $25 \mu \mathrm{l}$ volume containing $10 \mathrm{Mm}$ Tris- $\mathrm{HCl}$ buffer at $\mathrm{pH} 8,50 \mathrm{mM} \mathrm{KCl}, 1.5 \mathrm{mM} \mathrm{MgCl}, 0.2 \mathrm{mM}$ of each dNTP (Bioron, Germany), $0.2 \mu \mathrm{M}$ of each primer, 20 ng genomic DNA and $3 \mathrm{U}$ of Taq DNA polymerase (Bioron, Germany). The polymerase chain reaction was performed in a Techne thermocycler (Germany) with the following parameters: $5 \mathrm{~min}$ initial denaturation step at $94^{\circ} \mathrm{C}$, followed by 40 cycles of $45 \mathrm{~s}$ at $94^{\circ} \mathrm{C} ; 1 \mathrm{~min}$ at $55^{\circ} \mathrm{C}$ and $1 \mathrm{~min}$ at $72^{\circ} \mathrm{C}$. The reaction was completed with a 7 min extension step at $72^{\circ} \mathrm{C}$. The amplification products were visualized by running on $2 \%$ agarose gels. The fragment size was estimated using a $100 \mathrm{bp}$ molecular size ladder (Fermentas, Germany). In order to identify reproducible bands, the experiment was replicated 3 times.

ISSR bands obtained were coded as binary characters (presence $=1$, absence $=0$ ). Grouping of the plant specimens was done by different clustering and ordination methods such as UPGMA (Unweighted paired group using average), and MDS (Multidimensional scaling) (Podani 2000). These analyses were done in PAST ver. 2.17 (Hammer et al. 2012).

\section{Results}

\subsection{Species identification based on morphological characters and its marker}

Our preliminary identification based on selected morphological characters resulted in nine distinct species (Table 3).
Table 3: Identified species based on morphological characters.

Table 3: Vrste, določene na osnovi morfoloških znakov.

\begin{tabular}{lll} 
No. & $\begin{array}{l}\text { Species identified with } \\
\text { morphological characters }\end{array}$ & $\begin{array}{l}\text { Localities in } \\
\text { Table } 1\end{array}$ \\
\hline 1 & Tamarix arceuthoides Bge. & 11 \\
2 & T. ramosissima Ledeb. & $8,9,10$ \\
3 & T. karkalensis Lour. & 19 \\
4 & T. szowitsiana Bge. & 12,13 \\
5 & T. meyeri Boiss., & $4,5,6,7$ \\
6 & T. androssowii Litw. & $14,15,16,17,18$ \\
7 & T. androssowii var. transcaucassica & 20 \\
& $\quad$ (Bunge) Qaiser & $1,2,3$ \\
8 & T. aucheriana (Decne. ex Walp.) & \\
& B. R. Baum. & 21,22 \\
9 & T. mascatensis Bge & \\
\hline
\end{tabular}

One sample of any species ITS sequences were obtained and compared with available sequences in Tamarix species. The results are provided in Table 4. All identified species had at least $95 \%$ homology with the reported ITS sequence for the same taxa in NCBI (National Center for Biotechnology Information).

Table 4: Tamarix species identified and their ITS sequence homology to the reported species.

Tabela 4: Določene vrste rodu Tamarix in istorodnost njihovih ITS sekvenc z obravnavanimi vrstami.

\begin{tabular}{lcl}
\hline Species & Homology \% & Accession No. \\
T. aucheriana & 100 & AF484762 \\
T. arceuthoides & 95 & AY452028 \\
T. mascatensis & 99 & KT809493 \\
T. ramosissima & 98 & KM657148 \\
T. karkalensis & 97 & KJ377278 \\
T. meyeri & 96 & KJ729661 \\
T. androssowii & 99 & KT377273 \\
T. androssowii var. trans- & - & - \\
\multicolumn{1}{c}{ caucassiva } & & \\
T. szowitsiana & - & - \\
\hline
\end{tabular}

\subsection{Relationship between species based on morphological studies}

Different clustering methods (WARD, NJ and UPGMA dendrograms) based on 42 morphological characters in identical species produced similar results. Therefore, only UPGMA dendrogram is presented (Figure 2). Plants of 


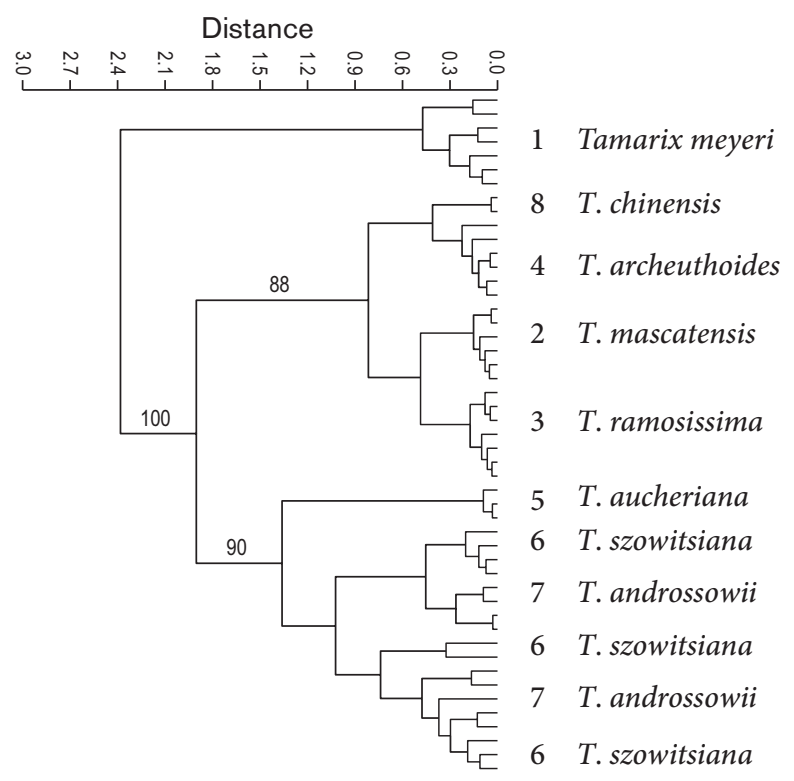

Figure 2: UPGMA dendrogram of Tamarix species based on morphological data.

Slika 2: Dendrogram UPGMA vrst rodu Tamarix na osnovi morfoloških podatkov.

each species were grouped together and formed a distinct cluster. Therefore, the studied species were delimited based on morphological characters.

In PCoA plot of the morphological characters (Figure 3), the species in the sect. Tamarix viz. T. arceuthoides, T. mascatensis and T. ramosissima and T. karkalensis were grouped in one cluster. Similarly, the species of the sect. Oligadenia viz. T. meyerii, T. androssowii, T. szowitsiana and were grouped together, while T. auscheriana of the

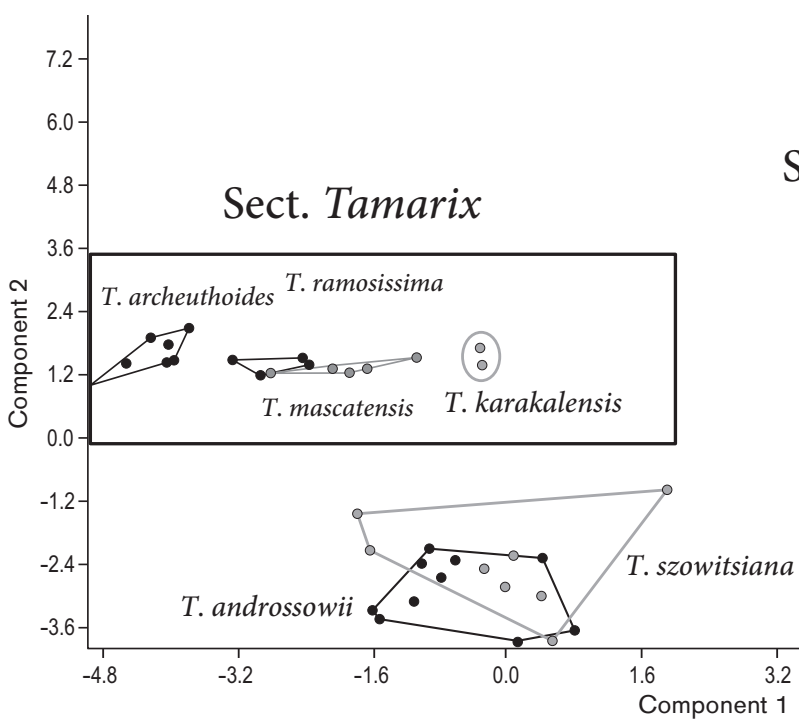

Figure 3: PCoA plot of Tamarix species based on morphological character. Slika 3: Graf PCoA vrst rodu Tamarix na osnovi morfoloških podatkov. sect. polyadenia was placed far from the other species. In addition T. aucheriana was also placed far from the other study species within the sec. Polyadenia. This is due to stamen number, width of inflorescence and disc diameter.

Within the sec. Oligadenia, T. androssowii and T. szowitsiana show close affinity due to its ratio of pedicel size/ calyx size, inflorescence, length of inflorescence, length of external calyx and leaf length. While, T. meyeri is placed far from of them due to leaflet length, leaflet width, width of external and internal calyx.

\subsection{Relationship between species based on its studies}

UPGMA, NJ, and maximum likelihood (ML) methods in identical species produced similar results for ITS data. Therefore, only the NJ tree is presented (Figure 4). In general, the studied species from different sections were placed intermixed. Therefore, ITS data could not delimit the species according to the presumed sections in genus Tamarix. All the obtained clades had high bootstrap value (>80\%). Tamarix karkalensis differed the most from the other species and formed a single clade. This was followed by $T$. arceuthoides. The samples identified as $T$. androssowii were placed close to each other.

\subsection{Introgression evidenced}

Molecular phylogeny of the studied species and their relationship was not in agreement with the species tree of morphological characters and with taxonomic classification of the genus.

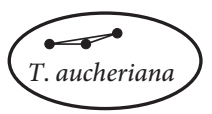

Sect. Polyadenia 


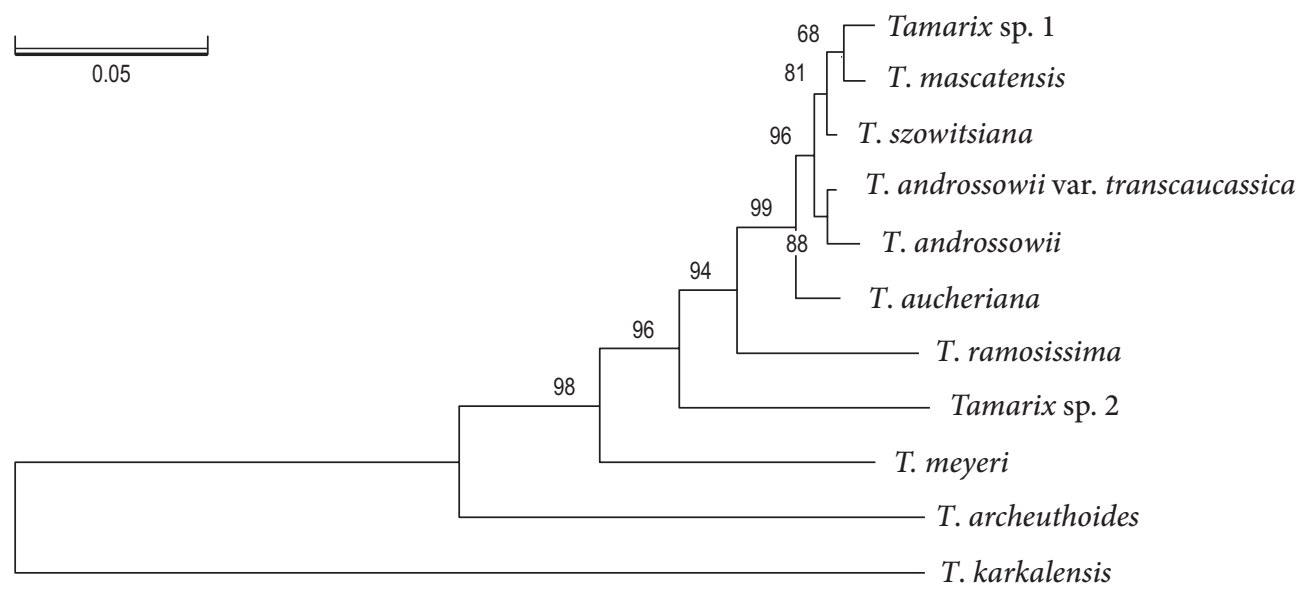

Figure 4: NJ tree of Tamarix species based on ITS sequences. Numbers above branches are bootstrap value.

Slika 4: Drevo združevanja NJ vrst rodu Tamarix na osnovi ITS sekvenc. Številke nad vejami prikazujejo število bootstrap ponovitev.

Therefore, the potential gene flow among the studied species was investigated by HGT (Horizontal Gene Transfer) analysis with the help of T-REX program (Figure 5). The HGT tree is based on both morphological and ITS tree of the studied species. The results revealed some degree of gene flow between T. meyerii and almost all the other studied species in the region. Moreover, $T$.
Karkalensis had gene exchange with T. arceuthoides, while, T. ramosissima exchanged gene with $T$. arceuthoides. The plant named Tamarix sp1, was therefore, considered to be $T$. androssowii that was produced by gene flow between this species and T. meyerii. However, Tamarix sp2 was considered to be new variety of T. szowitsiana, formed by introgression between T. szowitsiana and T. meyerii.

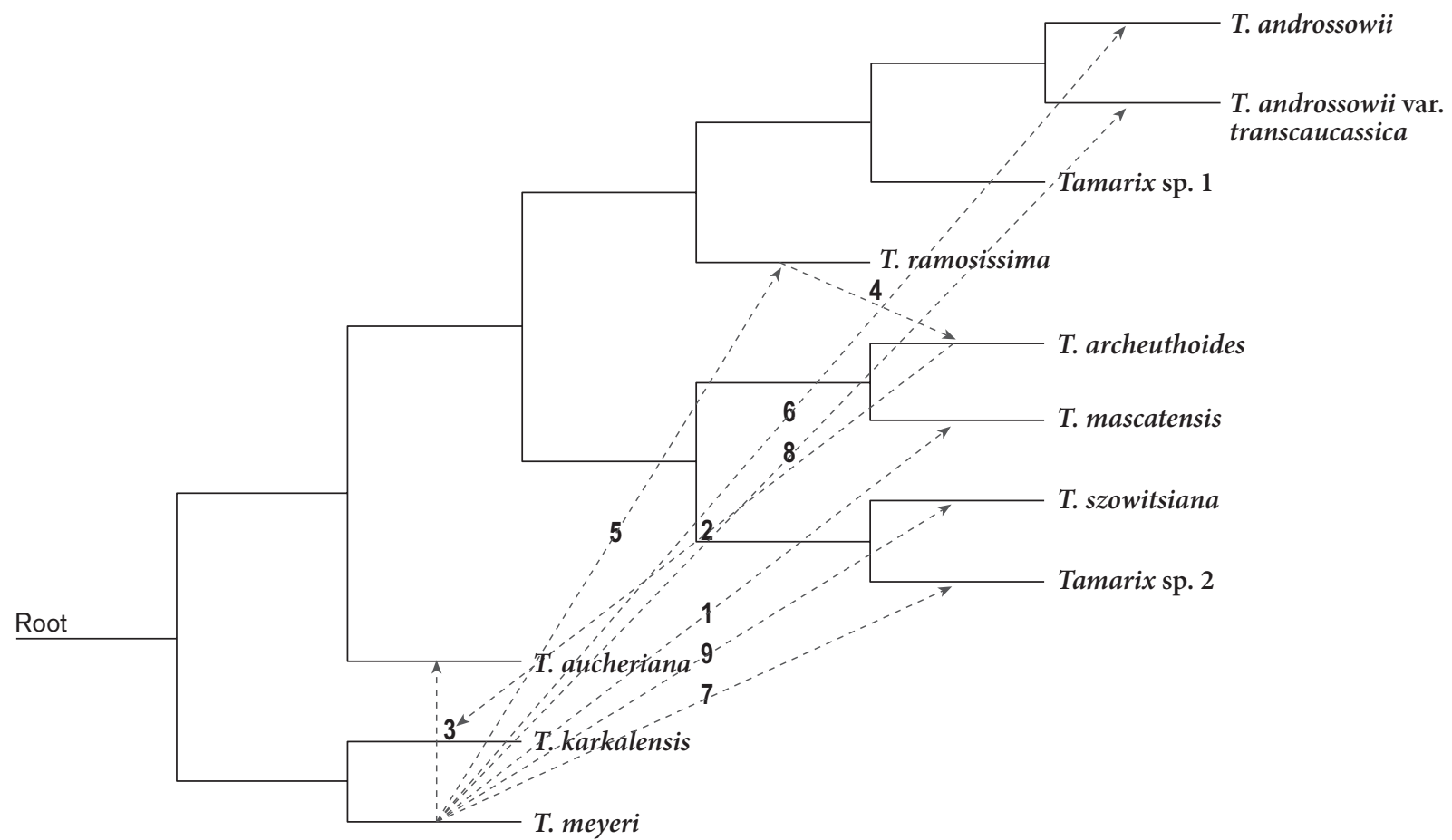

Figure 5: HGT tree of Tamarix species based on morphological and ITS data, showing gene flow among these taxa.

Slika 5: Drevo HGT vrst rodu Tamarix na osnovi morfoloških in ITS podatkov, ki prikazuje pretok genov med taksoni. 
As evidenced in UPGMA tree of morphological characters (Figure 6), plants of T. szowitsiana and T. androssowii were placed intermixed due to variability and overlap in their morphological characters. Detailed morphological study of these plants in six geographical populations revealed that some plants have a two or more mixture of species characters. The same result was obtained by ISSR study.
UPGMA tree (Figure 6) and MDS plot (Figure 7) of ISSR data revealed admixture of samples in T. szowitsiana (coded 1), T. androssowii (coded 2) and the trees with mixture of characters from both species (coded 3$)$.

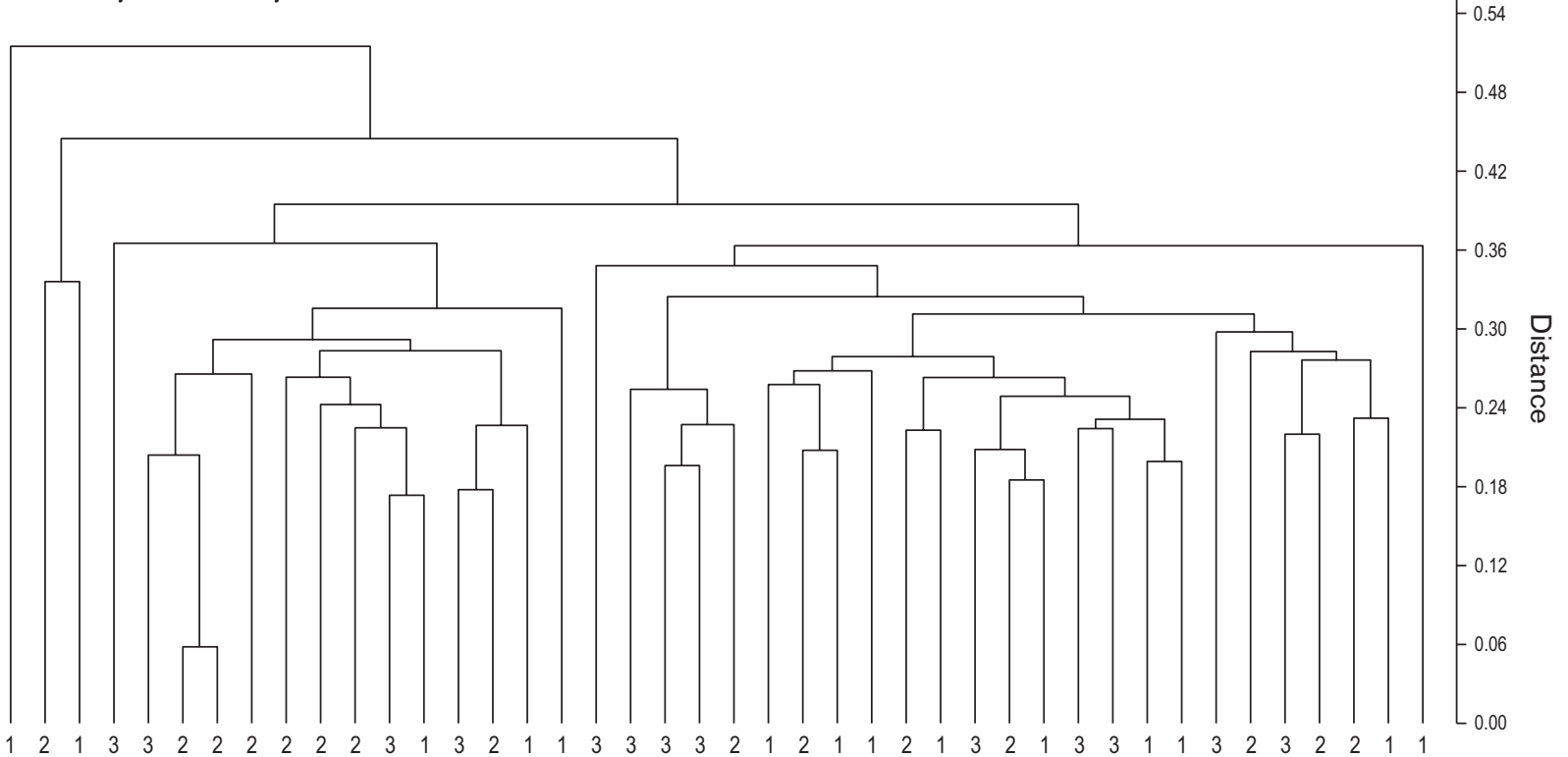

Figure 6: UPGMA tree of the studied samples based on ISSR data.

Slika 6: Drevo združevanja UPGMA preučevanih vzorcev na osnovi ISSR podatkov.

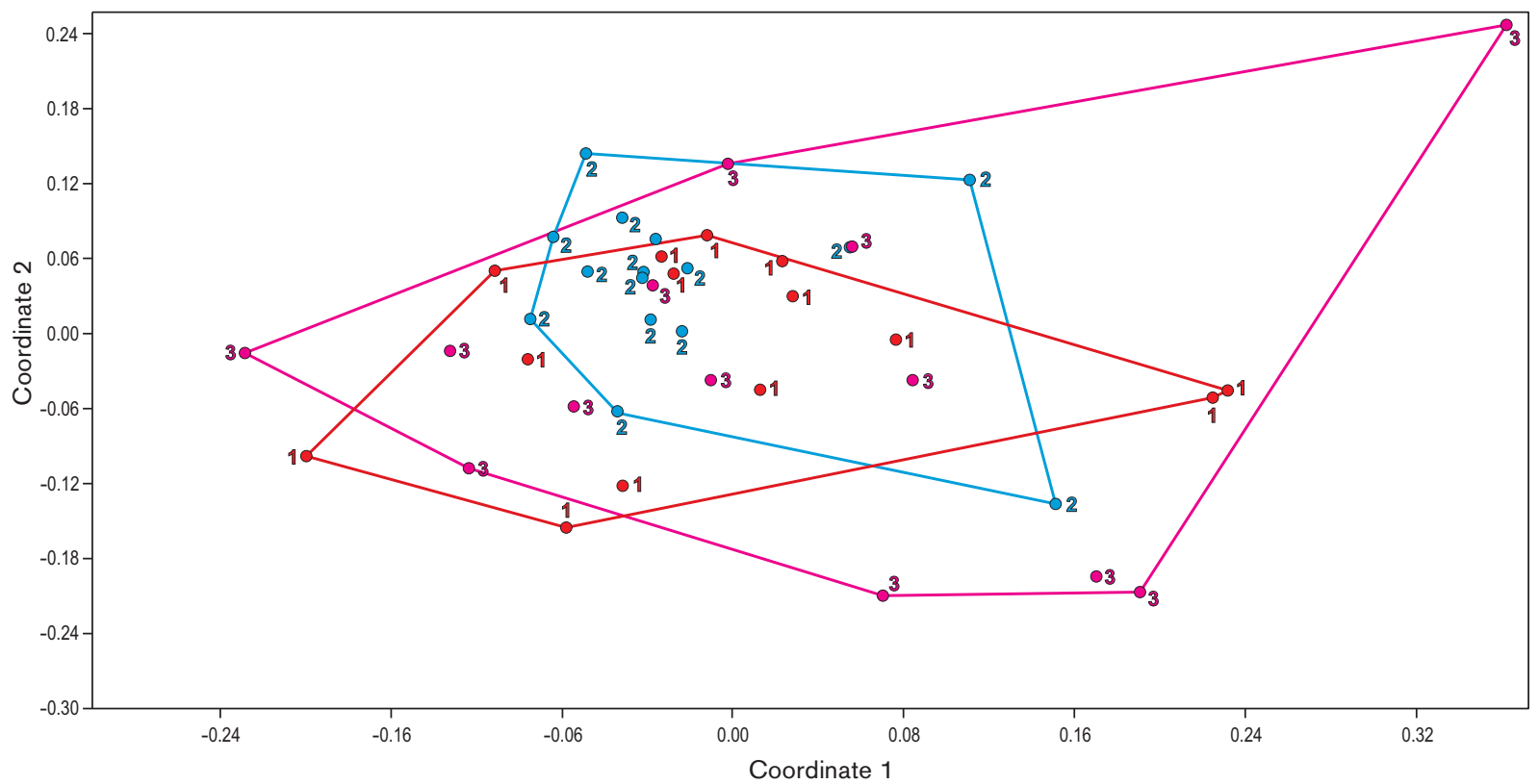

Figure 7: MDS plot of the studied samples based on ISSR data.

Slika 7: Graf MDS preučevanih vzorcev na osnovi ISSR podatkov. 


\section{Discussion}

Tamarix species act against deforestation in Iran, therefore identification of these species and their hybrids throughout the country is crucial for conservation strategy. Tamarix species grow in different geographical populations in the country and face diverse environmental conditions. It is usually expected that species that grow in different geographical populations, show genetic and morphological variability (Sheidai et al. 2018). The same holds true for Tamarix species (Ijbari et al. 2014, Sheidai et al. 2018). Moreover, Tamarix species are known to form frequent inter-specific hybrids (Sheidai et al. 2018). Due to morphological overlaps in Tamarix species as a result of inter-specific gene flow, identification of Tamarix species is problematic and needs to have clear cut differentiating morphological features. The present study revealed that, it is better to start morphological identification of Tamarix species, first by considering 4-merous flowers versus 5-merous flowers. Secondly, characters like shape of disks and leaves should be considered for Tamarix identification (Obermeyer 1978, Bredenkamp \& Phepo 2008).

However, we may still some degree of overlap even in these characters, therefore, it is better to accompany morphological identification with molecular data support. Combination of both morphological and molecular results provide a more reliable and consistent method of identifying Tamarix species.

Our second main objective in this study was to reveal gene flow or hybridization within Tamarix species. Molecular tools also provide the means to investigate the genetic diversity within and among populations, and can also detect hybridization and introgression patterns between closely related species (Le Roux \& Wieczorek 2008).

Hybridization is a driving force of invasion, when new species are introduced into a new region, they may meet closely related species or genotypes and form hybrid. These hybrid individuals have high genotypic fitness in the newly-invaded habitat (Gaskin \& Kazmer 2009). Hybridization followed by introgression (natural back-crossing between hybrids and parental lineages) can provide necessary genetic variability for Tamarix species to cope with environmental condition they face (Schierenbeck \& Ellstrand 2009). These hybrids may survive in extreme habitats that are not suitable for either of the parent taxa, as was reported in Helianthus (Riesberg et al. 2003). The present study revealed the occurrence of inter-specific hybridization or introgression between T. meyeri, T. szowitsiana, and T. androssowii. The ecotypes formed show the separation of a single lineage into separate lineages that act as the initial stage of genetic divergence, which in some cases may lead to speciation (Schaal et al. 2003).
Masoud Sheidai (D), https://orcid.org/0000-0003-3983-6852

Maryam Keshavarzi (D), https://orcid.org/0000-0003-3032-9408

Fahimeh Koohdar (D), https://orcid.org/0000-0002-7878-1906

\section{References}

Arianmanesh, R., Mehregan, I., Nejadsatari, T. \& Assadi, M. 2015: Molecular phylogeny of Tamarix (Tamaricaceae) species from Iran based on ITS sequence data. European Journal of Experimental Biology 5: 44-50.

Baldwin, B. G., Sanderson, M. J., Porter, J. M., Wojciechowski, M. F., Campbell, C. S. \& Donoghue, M. J. 1995: The ITS region of nuclear ribosomal DNA-A valuable source of evidence on Angiosperm phylogeny. Annals of the Missouri Botanical Garden 82: 247-277.

Baum, B. R. 1967: Introduced and naturalized tamarisks in the United States and Canada [Tamaricaceae]. Baileya 15: 19-25.

Baum, B. R. 1978: The Genus Tamarix. Jerusalem, Israel: Israel Academy of Sciences and Humanities.

Bredenkamp, C. \& Phepho, N. 2008: Hybridization of Tamarix usneoides and Tamarix ramosissima. Unpublished. South African Botanical Institute.

Enninful, E. K. \&Torvi, D. A. 2008: A variable property heat transfer model for predicting soil temperature profiles during simulated wildland fire conditions. International Journal of Wildland Fire 17: 205-213.

Brotherson, J. D. \& Winkel, V. 1986: Habitat relationships of saltcedar (Tamarix ramosissima). The Great Basin Natural 46: 535-541.

Campbell, J. Y., Lo, A. \& Mackinlay, A. C. 1997: The Econometrics of Financial Markets Princeton University Press, Princeton, N.J.

Gaskin, J. F. 2003: Tamaricaceae. In: Kubitzki, K \& Bayer, C. (eds.). The Families and Genera of Vascular Plants. Springer. pp. 363-368.

Gaskin, J. F. \& Kazmer, D.J. 2009: Introgression between invasive saltcedars (Tamarix chinensis and T. ramosissima) in the USA. Biological Invasions 11: 1121-1130.

Gaskin, J. F. \& Schaal, B. A. 2002: Hybrid Tamarix widespread in U.S. invasion and undetected in native Asian range. Proceedings of the National Academy of Sciences of the United States of America 99: 11256-11259

Gaskin, J. F. \& Schaal, B.A. 2003: Molecular Phylogenetic Investigation of U. S. Invasive Tamarix. Systematic Botany 28: 86-95.

Hammer, Ø., Harper, D. \& Ryan, P. D. 2012: PAST: Paleontological Statistics software package for education and data analysis. Palaeontologia Electronica 4: 1-9.

Heywood, V. H., Brummitt, R. K., Culham, A. \& Seberg, O. 2007: Flowering Plant Families of the World. Kew: Royal Botanic Gardens.

Ijbari, H., Sheidai, M., Mehrabian, A. R., Noormohammadi, Z. \& Ghasemzadeh-Baraki, S. 2014: K-means clustering and STRUCTURE analyses of genetic diversity in Tamarix L. accessions. Turkish journal of botany 38: 1080-1094. 
Križman, M., Jakše, J., Baričević, D., Javornik, B. \& Prosek, M., 2006: Robust CTAB activated charcoal protocol for plant DNA extraction. Acta agriculturae Slovenica 87: 427-433.

Le Roux, J. \& Wieczorek, A.M. 2008: Molecular systematic and population genetics of biological invasions: towards a better understanding of invasive species management. Annals of Applied Biology 157: 1-17.

Mayonde, S. G., Cron, G. V., Gaskin, J. F. \& Byrne, M. J. 2015: Evidence of Tamarix hybrids in South Africa, as inferred by nuclear ITS and plastid trnS-trnG DNA sequences. South African Journal of Botany 96: 122-131.

Mayonde, S. G., Cron, G. V., Gaskin, J. F. \& Byrne, M. J. 2016: Tamarix (Tamaricaceae) hybrids: the dominant invasive genotype in southern Africa. Biological Invasions 18: 3575-3594.

Mayonde, S, Cron, G.V, Glennon, K. L \& Byrne, M. J. 2019: Genetic diversity assessment of Tamarix in South Africa - Biocontrol and conservation implications. South African Journal of Botany 121: $54-62$.

Obermeyer, A. A. 1976: Tamaricaceae. In: Ross, J.H. (ed.): Flora of southern Africa. Botanical Research Institute, Department of agricultural technical services, Pretoria.

Podani, J. 2000. Introduction to the Exploration of Multivariate Data. Backhuyes, Leiden, 407 pp.

Schaal, B. A., Gaskin, F. \& Caicedo, A. L. 2003: Phylogeography, haplotype trees, and invasive plants. Journal Heredity 94: 197-204.
Rieseberg, L. H., Raymond, O., Rosenthal, D. M., Lai, Z., Livingstone, K., Nakazato, T., Durphy, J. L., Schwarzbach, A. E., Donovan, L. A. \& Lexer, C. 2003: Major ecological transitions in wild sunflowers facilitated by hybridization. Science 301: 1211-121.

Schierenbeck, K. A. \& Ellstrand, N. C. 2009: Hybridization and the evolution of invasiveness in plants and other organisms. Biological Invasions 11: 1093-1105.

Schiman-Czeika, H. 1964: Flora Iranica. Graz: Akademische Druck-u. Verlagsanstalt, Vol. 4.

Sheidai, M., Zanganeh, S., Haji-Ramezanali, R., Nouroozi, M., Noormohammadi, Z. \& Ghsemzadeh-Baraki, S. 2013: Genetic diversity and population structure in four Cirsium (Asteraceae) species. Biologia 68: 384-397.

Sheidai, M., Ziaee, S., Farahani, F., Talebi, S.M., Noormohammadi, Z. \& Hasheminejad Ahangarani Farahani, Y. 2014: Infra-specific genetic and morphological diversity in Linum album (Linaceae). Biologia 69: 32-39.

Sudbrock, A. 1993: Tamarisk control-fighting back: an overview of the invasion, and a low-impact way of fighting it. Restoration and Management. Notes 11:31-34.

Tamura, K., Peterson, D., Peterson, N., Stecher, G., Nei, M., Kumar, S. 2012: MEGA5: molecular evolutionary genetics analysis using maximum likelihood, evolutionary distance, and maximum parsimony methods. Molecular Biology and Evolution 28: 2731-2739. 